\title{
Does Neuroectodermal Stem Cells Transplantation Restore Neural Regeneration and Locomotor Functions in Compressed Spinal Cord Injury Rat Model?
}

\author{
¿El Trasplante de Células Madre Neuroectodérmicas Restaura la Regeneración Neural y las \\ Funciones Locomotoras en el Modelo de Rata con Lesión de la Médula Espinal Comprimida?
}

\author{
Saleh Al-Karim ${ }^{1,3}$; Wafaa S. Ramadan ${ }^{2,3,4}$; Ghada A. Abdel-Hamid ${ }^{2,3,5}$ \& Fatma Al Qudsi ${ }^{1,3}$
}

\begin{abstract}
AL-KARIM, S.; RAMADAN, W. S.; ABDEL-HAMID, G. A. \& AL QUDSI, F. Does neuroectodermal stem cells transplantation restore neural regeneration and locomotor functions in compressed spinal cord injury rat model? Int. J. Morphol., 37(1):349-357, 2019.

SUMMARY: The aim of this study was to determine the possible regenerative effect of neuroectodermal stem cells on the ultrastructural, and locomotor function resulting from compressed injury to the spinal cord in a rat model. Forty male rats were divided into control and sham groups (20 rats each). Compressed spinal cord injured (CSCI) were forty rats which subdivided equally into: untreated, treated by neuroectodermal stem cells (NESCs). After four weeks, all rats in different groups were scarified, samples were taken from central, cranial, and caudal to the site of spinal cord injury. Specimens were prepared for light and electron microscopic examination. The number of remyelinated axons in central, cranial and caudal regions to the injured spinal cord after transplantation of NESCs was counted. The open field test assessed the locomotor function. Results revealed that compressed spinal cord injury resulted in loss and degeneration of numerous nerve fibers, myelin splitting and degeneration of mitochondria. Four weeks after transplantation of NESCs regenerated axons were noticed in cranial and central sites, while degenerate axons were noticed caudal to the lesion. Number of remyelinated axons was significantly increased in both central and cranial to the site of spinal cord injury in comparison with caudal region which had the least number of remyelinated axons. Transplantation of NESCs improved significantly the locomotor functional activity In conclusion, neuroectodermal stem cells transplantation ameliorated the histopathological and ultrastructural changes, and improved the functional locomotor activity in CSCI rat.
\end{abstract}

KEY WORDS: Neuroectodermal; Stem cells; Spinal cord; Injury; Regeneration; Rat.

\section{INTRODUCTION}

Spinal cord injury leads to enduring neurological deficits that affect about 2.5 million people in the world (Thuret et al., 2006). Patients with spinal cord injuries had extensive neurological disability with loss of sensory, motor and autonomic function (Ackery et al. 2004). Traumatic spinal cord injury resulted in hemorrhage and ischemia that lead to necrosis and neuoral loss (Kwon et al. 2004). Although there are no completely curative treatments presently accessible, recent animal studies evidenced efficacy of stem cell therapeutic strategies to improve functional and locomotor recovery after spinal cord injury (Thuret et al.; Kim et al., 2007; Nandoe et al., 2009a,b).

Spinal cord injury disturbs descending and ascending pathways that lead to damage of neurons and glia, demyelination and inflammation. Accordingly, there is loss of sensation movement, and autonomic control inferior to the site of spinal cord injury. Stem cell transplantation to the damaged spinal cord leads to functional recovery (Mcdonald et al., 2004). Moreover, experimental studies used rat model for spinal cord injury revealed that transplanted stem cells to the rats with spinal cord injury resulted in axonal regeneration, remyelination and motor recovery (Ogawa et al., 2002).

Since white matter in most spinal cord injuries was more damaged than gray matter, the majority of rat models for spinal cord injuries included contusion or compression injuries to white matter in the thoracic region of the vertebral column. Previous studies declared that no need for complete repair of the injured spinal cord to regain function; restoring

\footnotetext{
${ }^{1}$ Department of Biological Sciences, Faculty of Science, King Abdulaziz University, Jeddah, Saudi Arabia.

${ }^{2}$ Department of Anatomy, Faculty of Medicine, King Abdulaziz University, Jeddah, Saudi Arabia.

${ }^{3}$ Embryonic Stem Cell Unit, King Fahd Medical Research Center, King Abdulaziz University, Jeddah, Saudi Arabia.

${ }^{4}$ Department of Anatomy, Faculty of Medicine, Ain Shams University, Cairo, Egypt.

${ }^{5}$ Department of Anatomy, Faculty of Medicine, Suez Canal University, Ismaillia, Egypt.
} 
damaged white matter would be sufficient (Mcdonald et al.). This is hopeful for patients with spinal cord injuries when transplanted neuroectodermal cells may help recover motor function in their lower limbs to change their life completely.

Recent studies by our team (Ramadan et al. 2017), revealed that seven days after compressed injury in rats' spinal cord, histopathological changes as areas of cavitation, fibrinoid necrosis and astrocytosis were reported. In addition to ultrastructural changes, as swollen thinned myelin sheath and myelin splitting, besides degeneration of axoplasm. This study demonstrated the histological, immunohistochemical and ultrastructure effects of compressed spinal cord injury in rats, only at the site of the lesion, without treatment or assessment of locomotor functions. Accordingly, the aim of this study was to determine the possible regenerative effect of neuroectodermal stem cells on the ultrastructural, and locomotor changes resulting from compressed injury to the spinal cord in a rat model in three regions: central, cranial and caudal to the site of the spinal cord lesion.

\section{MATERIAL AND METHOD}

Thirty female mice were used for producing 10-days embryos to extract neuroectodermal stem cells. Eighty adult male rats were divided into four groups (20 rats each): con- trol, sham, compressed spinal cord injured (CSCI), treated by neuroectodermal stem cells (NESCs). Animals were purchased from the animal house of King Fahd Medical Research Center, King Abdulaziz University, and Jeddah, Saudi Arabia. All techniques were conducted according to the guidelines of the Canadian Council on Animal Care. The rats were fed a commercial diet and given water ad libitum. 10-days embryo were obtained from pregnant female mice then their head were dissected under a dissecting microscope. Preparation of cells to be cultured according to Kitani et al. (1991) was done. Cells were incubated for $7 \mathrm{~h}$ at $37{ }^{\circ} \mathrm{C}$ in humidified $5 \% \mathrm{CO}_{2}: 95 \%$ air. The neural precursor cell population persisted floating which isolated and were spread and attach to a plastic substrate in the culture medium. The fibroblastic cells' growth was inhibited in a selective medium. Cell proliferation amplified from day 0 to day 3, 7 days in culture (Kitani et al.) (Fig.1).

To induce CSCI in rats, a laminectomy was performed at level of tenth thoracic vertebra. The spinal cord injury was performed at level of T10, using a clip compression technique, described in details according to (Bakar et al., 2013) and previously by our team (Ramadan et al.). Eighty adult male rats were divided into control and sham groups (20 rats each). Compressed spinal cord injured (CSCI) were forty rats which subdivided into: untreated, treated by neuroectodermal stem cells (NESCs) (20 rats each). The laminectomy site was reexposed after anesthetizing rats, and a $10-\mu 1$ Hamilton syringe
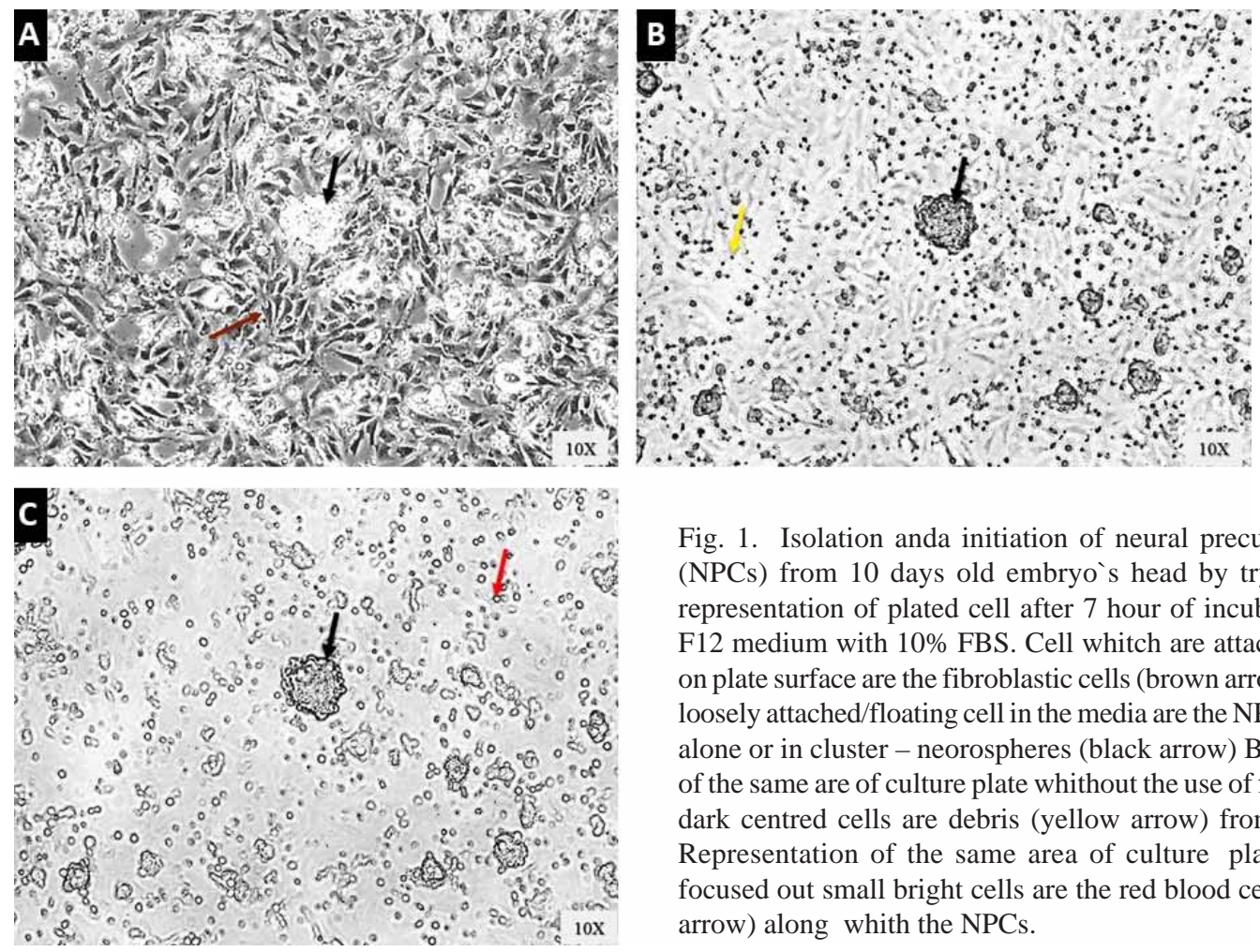

Fig. 1. Isolation anda initiation of neural precursor stem cells (NPCs) from 10 days old embryo`s head by trypsinization A. representation of plated cell after 7 hour of incubation grown in F12 medium with 10\% FBS. Cell whitch are attached and grown on plate surface are the fibroblastic cells (brown arrow) while bright loosely attached/floating cell in the media are the NPCs which floats alone or in cluster - neorospheres (black arrow) B. representation of the same are of culture plate whithout the use of filter. The Small dark centred cells are debris (yellow arrow) from dead cells C. Representation of the same area of culture plate while zoom focused out small bright cells are the red blood cells (RBCs) (red arrow) along whith the NPCs. 
(Hamilton, Reno, NV) was used to inject cell suspensions of neuroectodermal cells via (intramedullary route) along the midline of the spinal cord cranially and caudally to the site of spinal cord lesion in a total volume of $(250,000$ cells $)$ at a rate of $2 \mu \mathrm{l} / \mathrm{min}$. Animals received cyclosporine as an immunosuppressive one day before and two days after transplantation (Marques et al., 2010).

Ultrastructure evaluation. All rats in control, sham, CSCI and treated with NESCs were scarified after four weeks. Samples were taken of spinal cord tissues from all groups from central,cranial, and caudal to the site of spinal cord injury. Segments from the CSCI site were immersed in $4 \%$ paraformaldehyde, followed by immediate fixation in $3 \%$ glutaraldehyde and $1 \%$ paraformaldehyde in $0.1 \mathrm{M}$ phosphate buffer, $\mathrm{pH} 7.4$, for $3 \mathrm{~h}$, and then postfixed in $1 \%$ osmium tetroxide in the same buffer for 2 hours. The samples were dehydrated and embedded in epoxy resin mixture. Semithin sections of $1 \mathrm{~mm}$ thickness were stained with toluidine blue (Bozzola \& Russell, 1998). Ultrathin sections of $70 \mathrm{~nm}$ thick were cut using a diamond knife. The sections were stained with uranyl acetate, followed by lead citrate, and examined at $80 \mathrm{kV}$ with a JEM-2000EX transmission electron microscope (JEOL, Tokyo, Japan) at King Fahd Medical Research Center.

To assess the number of remyelinated axons in central, cranial and caudal regions in injured spinal cord after transplantation of NESCs, we used transmission electron microscope sections at $10000 \mathrm{X}$ magnification. Remyelinated axons were counted using the line-sampling technique according to Blight (1983). The average number of remyelinated axons within five $25 \times 25 \mathrm{~mm}^{2}$ areas along the radial line produced an approximation of the total number of axons within the epicenter zone, calculated as the number of axons per square millimeter.

Evaluation of locomotor function. The open field is a useful tool for assessing locomotive impairment in animal models of neuromuscular disease (Raben et al., 2000), as well as the efficacy of therapeutic drugs that may improve locomotion or motor function (Sali et al., 2012). Rats were tested in an open field consisting of a square metallic box (72 $\mathrm{cm}$ in diameter) surrounded by $49-\mathrm{cm}$ high transparent walls with an open top. Each activity chamber was cleaned with alcohol between tests to eliminate urine and olfactory cues from previous subjects. Rats in their cages were placed in the test room for acclimatization. They were then transferred to the test chambers, which were closed with their lids. The animals were left for $60 \mathrm{~min}$. The activity chambers were turned on and the accompanying software on the computer connected to the chambers was run. The appropriate command in the computer software was selected, causing the analyzer and software to start recording the activity levels, in line with the data collection parameters (Tatem et al., 2014). The test was repeated before the induction of CSCI, after the operation and by four weeks after transplantation of the NESCs/ESCs cells.

Statistical analysis. The results were presented as means \pm SDs, then statistically analyzed using one-way ANOVA, SPSS statistical software, version 19.0 (SPSS, Chicago, IL, USA) for Windows. $\mathrm{P} \leq 0.05$ was considered significant.

\section{RESULTS}

Semithin sections of the spinal cords of rats from the control and sham groups showed normal nerve fiber structure (Fig. 2 A,B). Seven days after CSCI, the loss of numerous fibers was evident (Fig. 2C). Four weeks after transplantation of NESCs, regenerated axons were noticed in cranial and central sites, while degenerate axons were noticed caudal to the lesion (Fig. 3).

Ultrastructure of sections of white matter from the spinal cord of rats from the control and sham groups revealed myelinated axons with normal axoplasm (Fig. 4 A,B). On the other hand, seven days after CSCI, sections showed myelin splitting, giving an onion-like appearance, as well as degeneration of the axoplasm (Fig. 5A). Others revealed a loss of mitochondrial cristae (Fig. 5B). Areas of demyelination were also noticed (Fig. 5C). Four weeks after NESCs transplantation to the site of lesion in the spinal cord, oligodendrocytes showed remyelination, and Schwann remyelination was also observed. Myelinated axons with degenerate mitochondria are also noted (Figs. 6 and 7). Number of remyelinated axons was significantlyincreased in both central and cranial to the site of spinal cord injury in comparison with caudal region which had the least number of remyelinated axons (Fig. 8).

Evaluation of locomotor function. For kinematic analysis, the videotaped rats were analyzed automatically using the spontaneous locomotor activity open-field test apparatus at KFMRC. The results showed that the duration of the movements performed by rats in the CSCI group decreased significantly $\mathrm{P} \leq 0.05$ in comparison with both, the control and sham groups. The frequency of repeated movement was also significantly $\mathrm{P} \leq 0.05$ decreased in CSCI group when compared with control and sham groups. Four weeks after transplantation o NESCs both the duration of the movements performed by rats and the frequency of repeated movement increased significantly $\mathrm{P} \leq 0.05$ in comparison CSCI group. (Figs. 9 and 10). 

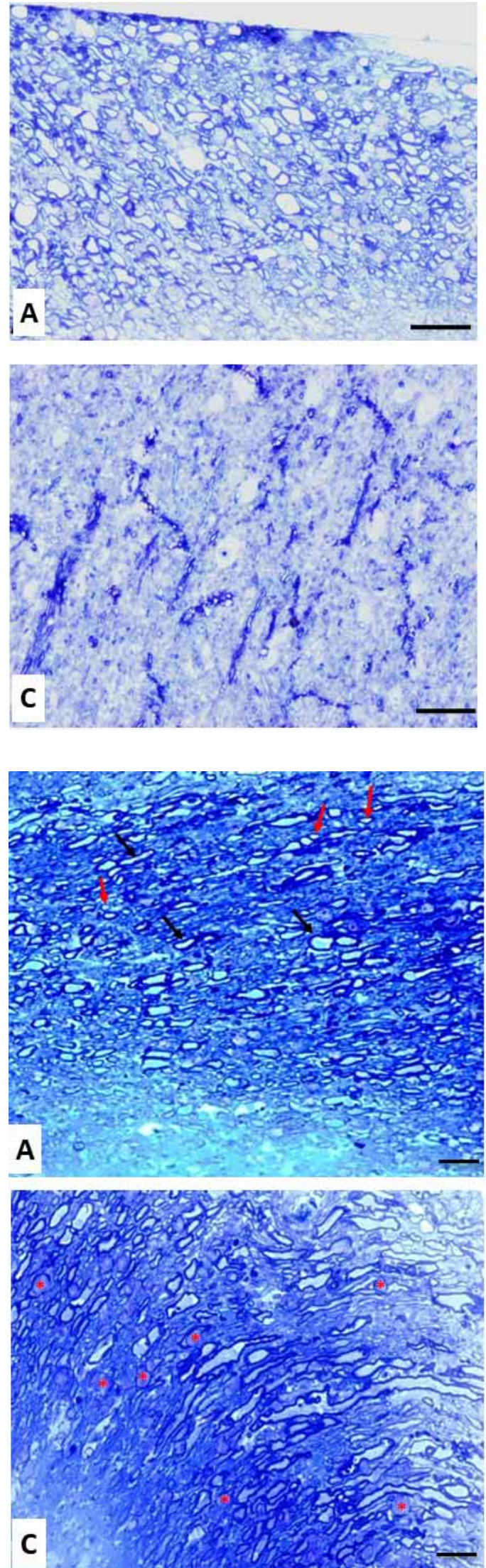

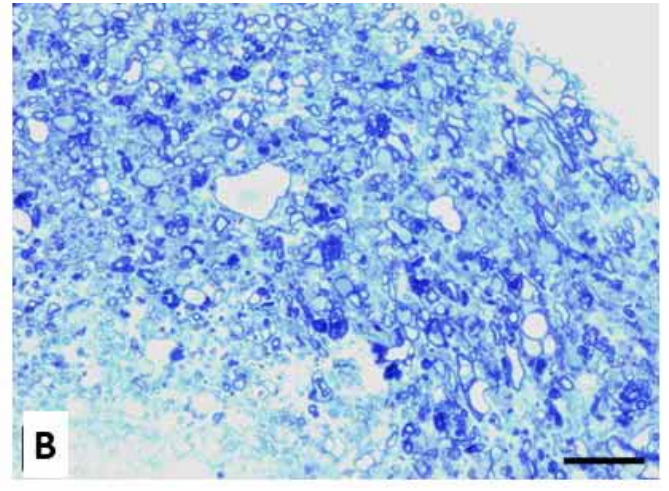

Fig. 2. Semithin sections of white matter from the spinal cord of the control (A) and sham (B) groups, showing normal structure of nerve fibers; seven days after CSCI (C), the obvious loss of nerve fibers is seen; scale bars A-C, $50 \mu \mathrm{m}$.

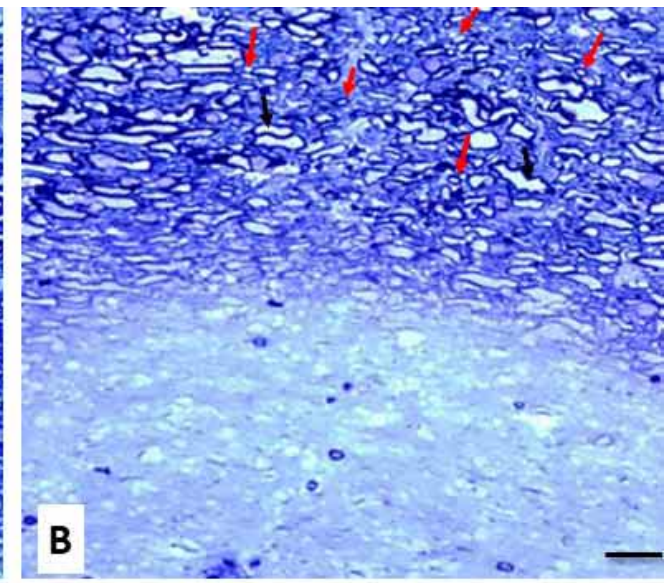

Fig. 3. Semithin sections of white matter from the spinal cord cranially (A), centrally (B), and caudally (C) to the site of CSCI; after transplantation of NESCs, regenerated axons were noticed in the cranial and central sites $(\mathrm{A}, \mathrm{C})$ (red arrows), beside the normal myelinated axons (black arrows); caudal to the lesion, degenerate axons $(*)$ were noticed $(\mathrm{C})$; scale bars A-C, $50 \mu \mathrm{m}$ 

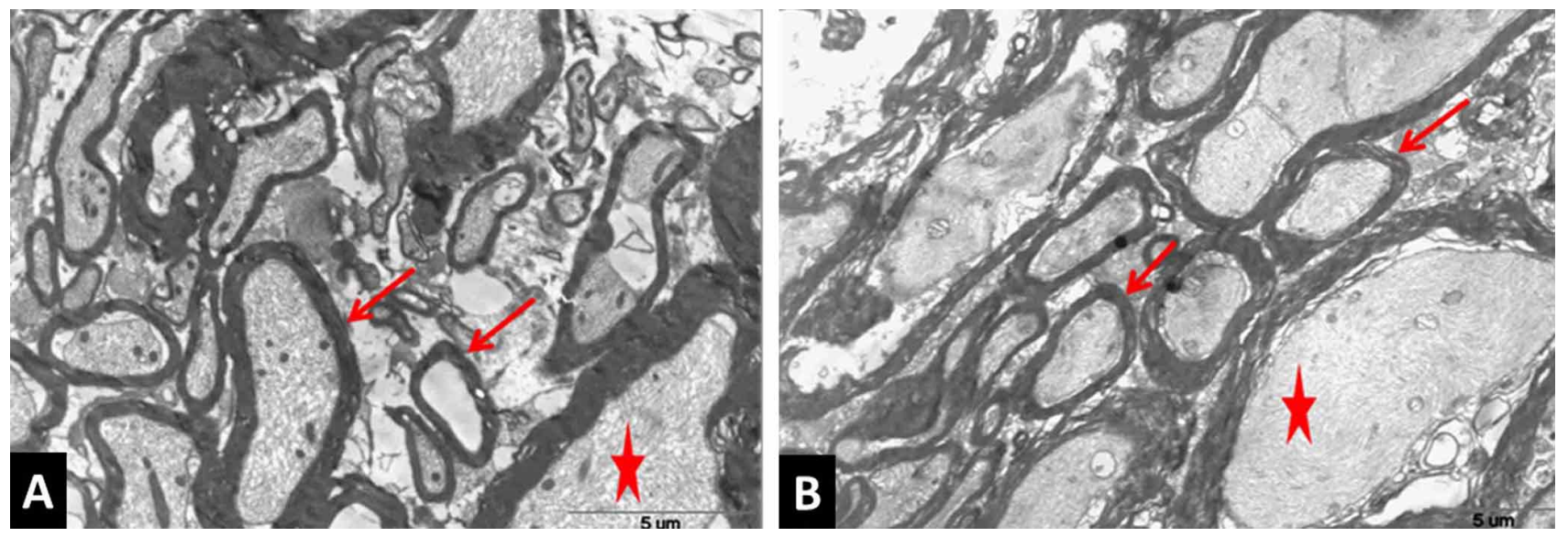

Fig. 4. Ultrathin sections of white matter from spinal cords for the control (A) and sham (B) groups, showing myelinated (red arrows) axons with normal axoplasm (stars). Scale bar: $5 \mu \mathrm{m}$.

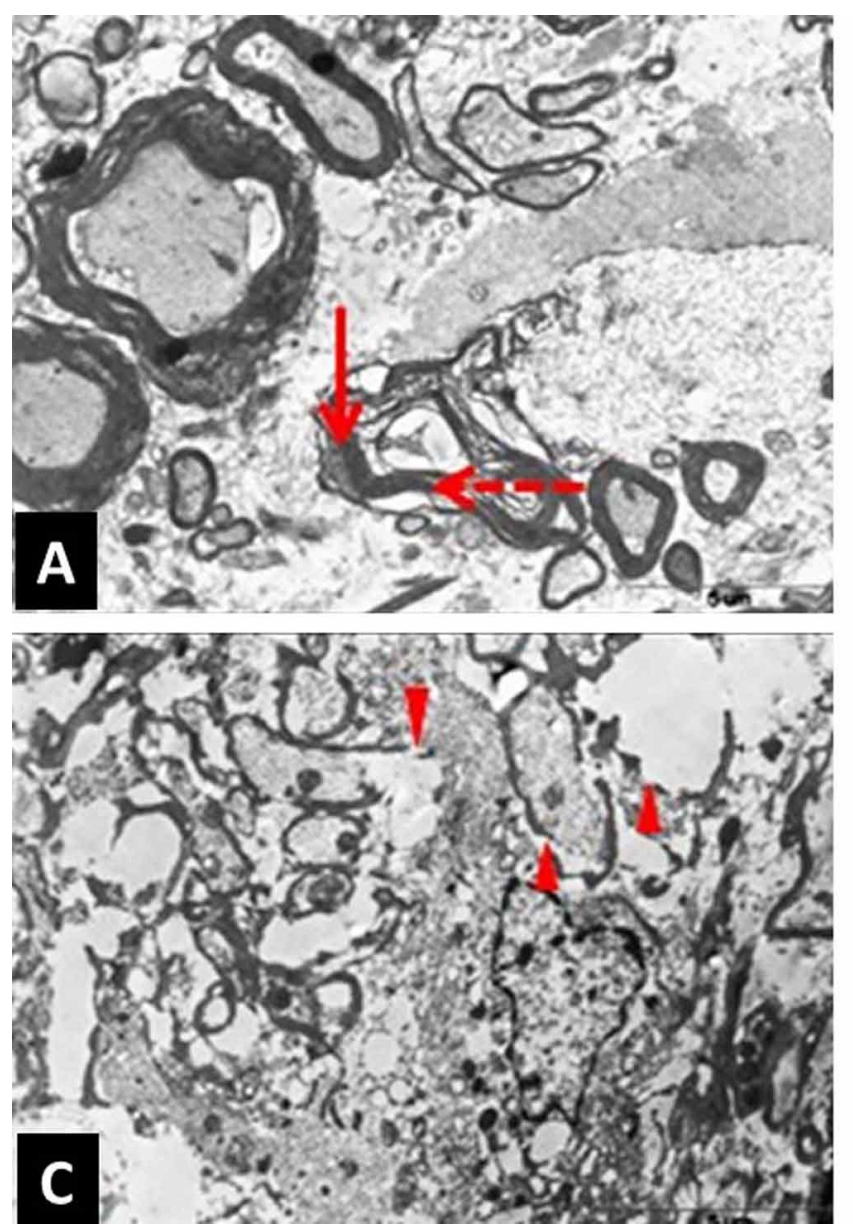

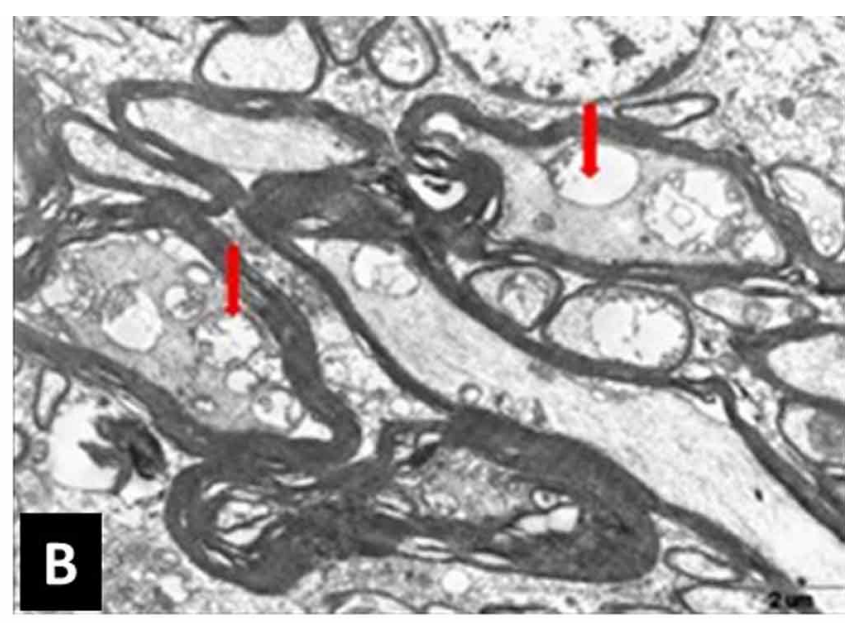

Fig. 5. Electron micrographs of sections of white matter from the spinal cords of rats seven days after CSCI, showing myelin splitting, giving an onion-like appearance (arrow); degeneration of the axoplasm (dashed arrow) (A), loss of mitochondrial cristae (thick arrows) (B), and areas of demyelination (triangles) (C) can be seen. Scale bar: $2 \mu \mathrm{m}$ 


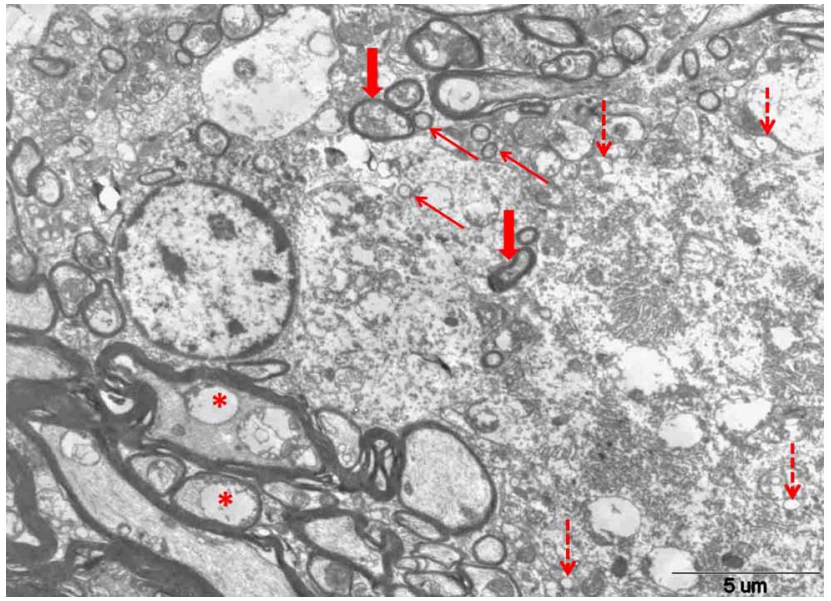

Fig. 6. Electron photomicrograph of the site central to the CSCI, four weeks after NESCs transplantation, showing oligodendrocyte remyelination (thin arrows), Schwann remyelination (thick arrows), or only cytoplasmic domain surrounded with basement membrane (dotted arrows); myelinated axons with degenerate mitochondria are also noted $(*)$.Scale bar: $5 \mu \mathrm{m}$.

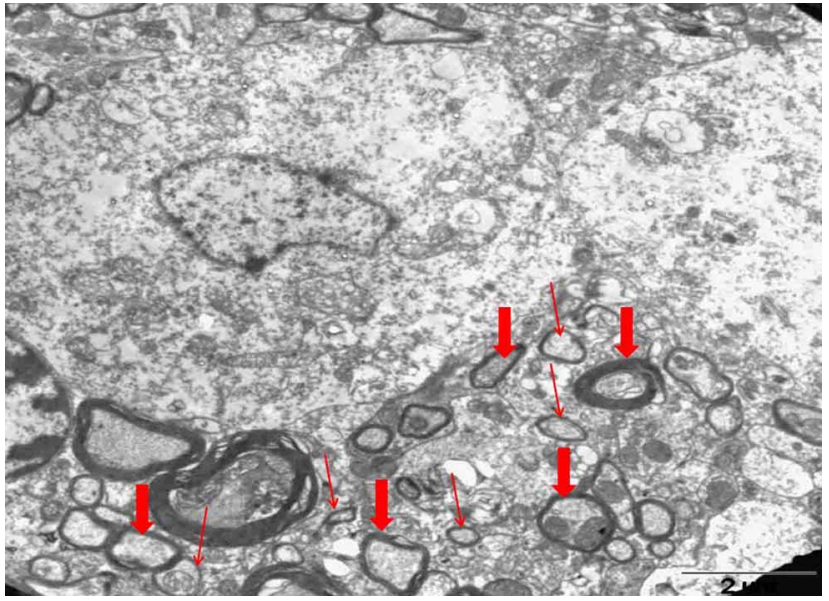

Fig. 7. Electron photomicrograph of the site central to the CSCI, four weeks after NESCs transplantation, showing remyelination of numerous oligodendrocytes (thin arrows), and Schwann remyelination (thick arrows). Scale bar: $2 \mu \mathrm{m}$.

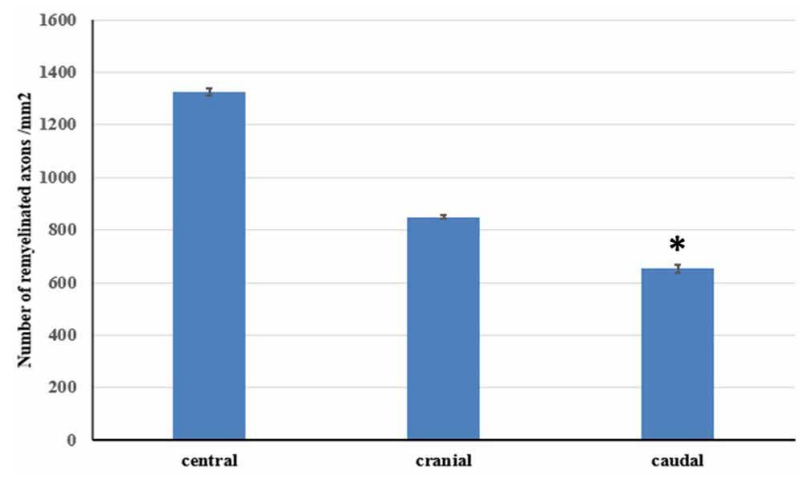

Fig. 8. Number of remyelinated axons was significantly $(* \mathrm{P} \leq 0.05)$ increased in both central and cranial to the site of spinal cord injury in comparison with caudal region.
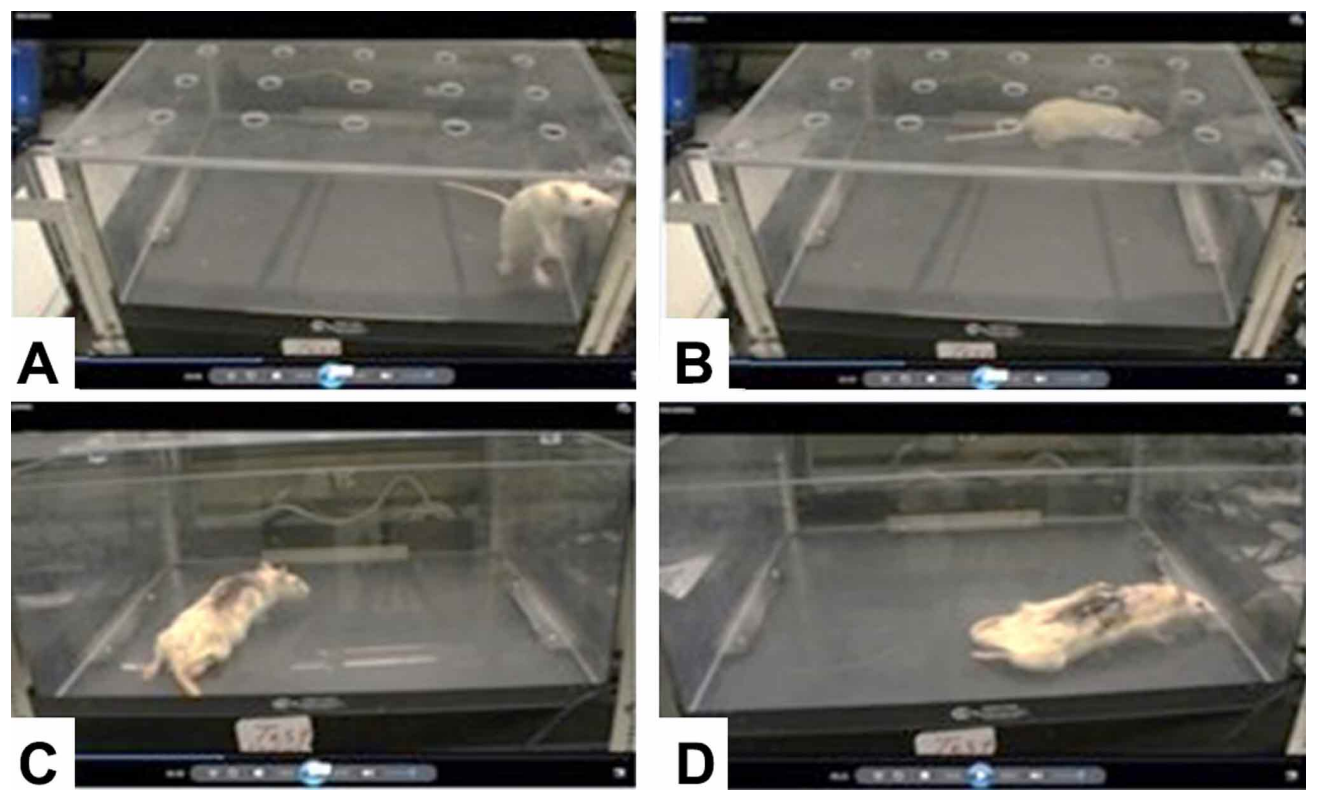

Fig. 9. Photographs of rats undergoing the spontaneous locomotor test; (A, B): rats from the control and sham groups; (C, D): rats seven days after CSCI, where loss of hind-limb function is evident. 


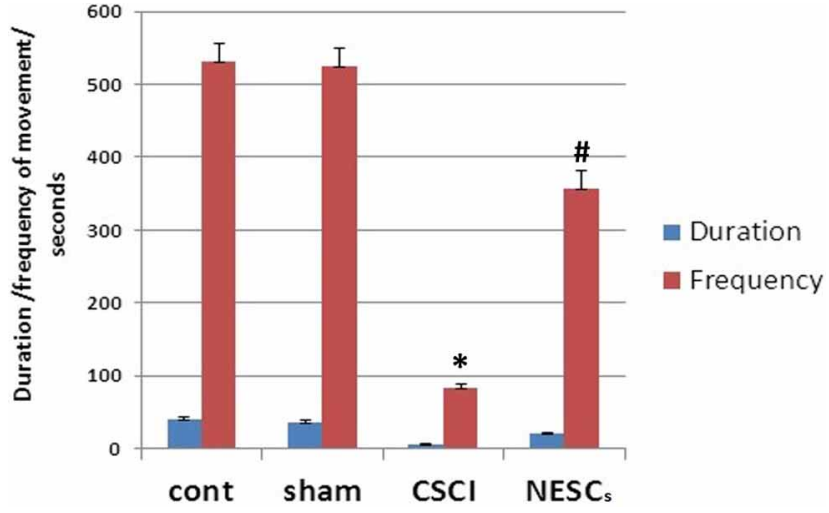

Fig. 10. Bar graph showing the mean duration and frequency of repeated movements.

\section{DISCUSSION}

Spinal cord injury treatment appeared frustrating and desperate as the notable mortality and morbidity, and limited therapeutic choices. Modern advances in nervous system injuries, repair and the development of regenerative interventions resulted in increasing optimism (Takahashi \& Yamanaka, 2006). Transplantation of neural stem cells is a crucial method for neural repair (Mcdonald et $a l$.). Embryonic stem cells have unique features, they replicate without aging, give rise to all types of body cells, give genetically normal cells and easily manipulated genetically (Gottlieb, 2002).

In the current study, the efficacy of neuroectodermal transplantation to alleviate histopathological changes on ultrastructure level and restore locomotor function after compressed spinal cord model in rat was investigated. The compression model was chosen to mimic the ventral compression that was discovered in the human clinical settings (Onifer et al., 2007). Therefore, compression and contusion models are more clinically applicable (Alhoseini \& Movaghar, 2014). Intramedullary route was selected to transplant NESCs as this route previously used in animals that included neural stem cells of several origins (Hatami $e t$ al., 2009; Fujimoto et al., 2012), oligodendrocytes (Sharp et al., 2010), motor neurons (Erceg et al., 2010), and bone marrow stem cells (Himes et al., 2006). This route compromised the cells' vulnerability that are transplanted to the injured spinal cord because of released cytotoxic chemokines (Bakshi et al., 2006).

Demyelination was a consistent histopathological feature at the site of the lesion seven days after CSCI as previously proved by Ramadan et al. Ultrastructural examination revealed axon demyelination, disruption and degeneration of mitochondria. This was in accordance with (Rawson et al., 2014), where it was proposed that axon degeneration is enhanced in the absence of mitochondria. The impairment of the activity of the mitochondrial respiratory chain complexes and the disruption of mitochondrial integrity plays a role in dysfunction of the neurons (Jeong et al., 2011). In addition, axon demyelination in spinal cord injury exposed the potassium channels of axons that held the membrane potential close to the resting potential, thus interfering with normal nerve conduction (Wu $\&$ Ren, 2008). Demyelination induced by damage and death of oligodendrocytes during the late phase of death after spinal cord injury in rats (Beattie et al., 2000; Dong et al., 2003).

The neuronal loss and demyelination in the present study account for the defective locomotor activity of the rats with spinal cord injuries. The use of a spontaneous locomotor activity open-field test revealed a statistically significant decrease in the frequency and duration of the movement in the experimental model of CSCI. Open field activity was chosen in this study for assessment of locomotor activity rather than the Basso-Beattie-Bresnahan (BBB) locomotor score. According to Metz et al. (2000) who considered open field activity test a valid measure of gross motor behavior in SCI animals' models. They claimed that the exploratory activity is sensitive to individual differences among animals with a low locomotor capacity and even severely damaged rats can show significant locomotor activity. Thus, this simple test is sensitive to a wide range of injuries. On the other hand, BBB assesses hindlimb function only and does not assess other movements which require coordinated spinal cord activity (Akhtar et al., 2008).

In general, animals with reduced muscle function will be less active and will have lower ambulatory activity. This is generally associated with the total distance traveled and movement time, as well as with increased rest time (Nagaraju et al., 2010). Furthermore, Vinay et al. (2002) described two types of approaches to locomotion: biomechanical and behavioral. The first is expressed by parameters such as distance traveled, average speed, and average potency, where the mechanical movement capacity of the animal was expressed. Those authors observed that the animal's ability to generate movement is linked to the level of maturation, activation, and coordination of the neural structures (sensory and motor).

In the present study, the most relevant finding is the remyelination occurring after transplantation of NESCs which more obvious in central and cranial regions than in caudal region to the site of CSCI. Moreover, number of remyelinated axons was significantly increased in both cen- 
tral and cranial to the site of spinal cord injury in comparison with caudal region which had the least number of remyelinated axons. Previous studies used different models with transplantation of several cells to evidenced remyelination in spinal cord injury (Kocsis et al., 2002; Bunge, 2002). In addition, transplantation of NESCs led to significant improvements in locomotor functional activity, where the frequency of movement was significantly increased and the duration of movement was almost four times longer than that in case of CSCI rats. Other studies, Keirstead et al. (2005) and Faulkner \& Keirstead (2005) reported significant gradual improvement in early stage after one month of stem cells transplantation. According to Sharp et al., used forelimb movement scores and found that the progressive improvement in the motor function was early as one week after stem cells transplantation. On the other hand, Erceg et al. found limited recovery of the hindlimb movements after 4 months of stem cells transplantation into transected spinal cord rat model.

\section{CONCLUSION}

The NESCs alleviated histopathological and ultrastructural changes due to CSCI, promoted remyelination, and enhanced functional locomotor activity.

\section{ACKNOWLEDGMENTS}

This study was supported by King Abdulaziz City for Science and Technology (KACST) by a research grant No.35-133.

AL-KARIM, S.; RAMADAN, W. S.; ABDEL-HAMID, G. A. \& AL QUDSI, F. ¿El trasplante de células madre neuroectodérmicas restaura la regeneración neural y las funciones locomotoras en el modelo de rata con lesión de la médula espinal comprimida? Int. J. Morphol., 37(1):349-357, 2019.

RESUMEN: El objetivo de este estudio fue determinar el posible efecto regenerativo de las células madre neuroectodérmicas en la función ultraestructural y locomotora de una lesión comprimida en la médula espinal en un modelo de rata. Cuarenta ratas macho se dividieron en grupos control y sham (20 ratas en cada grupo). La médula espinal lesionada (CSCI) tenía cuarenta ratas que se subdividieron de igual forma en los siguientes grupos: no tratadas, tratadas con células madre neuroectodérmicas (NESCs). $\mathrm{Al}$ término de cuatro semanas, todas las ratas en los diferentes grupos fueron escarificadas, se tomaron muestras de las áreas central, craneal y caudal en relación al sitio de la lesión de la médula espinal. Las muestras fueron preparadas para examen microscópi- co de luz y electrónica. Se contó el número de axones remielinizados en las regiones central, craneal y caudal de la médula espinal lesionada después del trasplante de NESCs. La prueba de campo abierto evaluó la función locomotora. Los resultados revelaron que la lesión de la médula espinal comprimida provocó la pérdida y degeneración de numerosas fibras nerviosas, la división de la mielina y la degeneración de las mitocondrias. Cuatro semanas después del trasplante de NESCs, se notaron axones regenerados en los sitios craneales y centrales, mientras que los axones degenerados se notaron caudal a la lesión. El número de axones remielinizados aumentó significativamente tanto en el centro como en el cráneo hasta el sitio de la lesión de la médula espinal en comparación con la región caudal que tenía el menor número de axones remielinizados. El trasplante de NESCs mejoró significativamente la actividad funcional locomotora. En conclusión, el trasplante de células madre neuroectodérmicas mejoró los cambios histopatológicos y ultraestructurales, y mejoró la actividad locomotora funcional en la rata CSCI.

PALABRAS CLAVE: Neuroectodérmica; Celulas madre; Médula espinal; Lesión; Regeneración; Rata.

\section{REFERENCES}

Ackery, A.; Tator, C. \& Krassioukov, A. A global perspective on spinal cord injury epidemiology. J. Neurotrauma, 21(10):1355-70, 2004.

Akhtar, A. Z.; Pippin, J. J. \& Sandusky, C. B. Animal models in spinal cord injury: a review. Rev. Neurosci., 19(1):47-60, 2008.

Alhoseini, M. S. \& Movaghar, V. R. Orthopedics, Physical Medicine and Rehabilitation Animal Models in Traumatic Spinal Cord Injury. In: Dionyssiotis, Y. (Ed.). Topics in Paraplegia. London, IntechOpen, 2014.

Bakar, B.; Köse, E. A.; Kupana Ayva, S.; Sarkarati, B.; Kasımcan, M. O. \& Kilınç, K. Effects of low-dose methotrexate in spinal cord injury in rats. Ulus. Travma Acil Cerrahi Derg., 19(4):285-93, 2013.

Bakshi, A.; Barshinger, A. L.; Swanger, S. A.; Madhavani, V.; Shumsky, J. S.; Neuhuber, B. \& Fischer, I. Lumbar puncture delivery of bone marrow stromal cells in spinal cord contusion: a novel method for minimally invasive cell transplantation. J. Neurotrauma, 23(1):55-65, 2006.

Beattie, M. S.; Farooqui, A. A. \& Bresnahan, J. C. Review of current evidence for apoptosis after spinal cord injury. J. Neurotrauma, 17(10):915-25, 2000

Blight, A. R. Cellular morphology of chronic spinal cord injury in the cat: analysis of myelinated axons by line-sampling. Neuroscience, 10(2):521-43, 1983.

Bozzola, J. J. \& Russell, L. D. Electron Microscopy: Principles and Techniques for Biologists. $2^{\text {nd }}$ ed. Sudbury, Jones and Bartlet Publishers, 1998.

Bunge, M. B. Bridging the transected or contused adult rat spinal cord with Schwann cell and olfactory ensheathing glia transplants. Prog. Brain Res., 137:275-82, 2002.

Dong, H.; Fazzaro, A.; Xiang, C.; Korsmeyer, S. J.; Jacquin, M. F. \& McDonald, J. W. Enhanced oligodendrocyte survival after spinal cord injury in Bax-deficient mice and mice with delayed Wallerian degeneration. J. Neurosci., 23(25):8682-91, 2003.

Erceg, S.; Ronaghi, M.; Oria, M.; Roselló, M. G.; Aragó, M. A.; Lopez, M. G.; Radojevic, I.; Moreno-Manzano, V.; Rodríguez-Jiménez, F. J.; Bhattacharya, S. S.; Cordoba, J. \& Stojkovic, M. Transplanted oligodendrocytes and motoneuron progenitors generated from human embryonic stem cells promote locomotor recovery after spinal cord transection. Stem Cells, 28(9):1541-9, 2010. 
Faulkner, J. \& Keirstead, H. S. Human embryonic stem cell-derived oligodendrocyte progenitors for the treatment of spinal cord injury. Transpl. Immunol., 15(2):131-42, 2005.

Fujimoto, Y.; Abematsu, M.; Falk, A.; Tsujimura, K.; Sanosaka, T.; Juliandi, B.; Semi, K.; Namihira, M.; Komiya, S.; Smith, A. \& Nakashima, K. Treatment of a mouse model of spinal cord injury by transplantation of human induced pluripotent stem cell-derived long-term self-renewing neuroepithelial-like stem cells. Stem Cells, 30(6):1163-73, 2012.

Gottlieb, D. I. Large-scale sources of neural stem cells. Annu. Rev. Neurosci., 25:38-407, 2002.

Hatami, M.; Mehrjardi, N. Z.; Kiani, S.; Hemmesi, K.; Azizi, H.; Shahverdi, A. \& Baharvand, H. Human embryonic stem cell-derived neural precursor transplants in collagen scaffolds promote recovery in injured rat spinal cord. Cytotherapy, 11(5):618-30, 2009.

Himes, B. T.; Neuhuber, B.; Coleman, C.; Kushner, R.; Swanger, S. A.; Kopen, G. C.; Wagner, J.; Shumsky, J. S. \& Fischer, I. Recovery of function following grafting of human bone marrow-derived stromal cells into the injured spinal cord. Neurorehabil. Neural Repair, 20(2):278-96, 2006.

Jeong, S. Y.; Crooks, D. R.; Wilson-Ollivierre, H.; Ghosh, M. C.; Sougrat, R.; Lee, J.; Cooperman, S.; Mitchell, J. B.; Beaumont, C. \& Rouault, T. A. Iron insufficiency compromises motor neurons and their mitochondrial function in Irp2-null mice. PLoS One, 6(10):e25404, 2011.

Keirstead, H. S.; Nistor, G.; Bernal, G.; Totoiu, M.; Cloutier, F.; Sharp, K. \& Steward, O. Human embryonic stem cell-derived oligodendrocyte progenitor cell transplants remyelinate and restore locomotion after spinal cord injury. J. Neurosci., 25(19):4694-705, 2005.

Kim, B. G.; Hwang, D. H.; Lee, S. I.; Kim, E. J. \& Kim, S. U. Stem cellbased cell therapy for spinal cord injury. Cell Transplant, 16(4):35564, 2007.

Kitani, H.; Shiurba, R.; Sakakura, T. \& Tomooka, Y. Isolation and characterization of mouse neural precursor cells in primary culture. In Vitro Cell. Dev. Biol., 27A(8):615-24, 1991.

Kocsis, J. D.; Akiyama, Y.; Lankford, K. L. \& Radtke, C. Cell transplantation of peripheral-myelin-forming cells to repair the injured spinal cord. J. Rehabil. Res. Dev., 39(2):287-98, 2002.

Kwon, B. K.; Tetzlaff, W.; Grauer, J. N.; Beiner, J. \& Vaccaro, A. R. Pathophysiology and pharmacologic treatment of acute spinal cord injury. Spine J., 4(4):451-64, 2004.

Marques, S. A.; Almeida, F. M.; Fernandes, A. M.; dos Santos Souza, C.; Cadilhe, D. V.; Rehen, S. K. \& Martinez, A. M. Predifferentiated embryonic stem cells promote functional recovery after spinal cord compressive injury. Brain Res., 1349:115-28, 2010.

McDonald, J. W.; Becker, D.; Holekamp, T. F.; Howard, M.; Liu, S.; Lu, A.; Lu, J.; Platik, M. M.; Qu, Y.; Stewart, T. \& Vadivelu, S. Repair of the injured spinal cord and the potential of embryonic stem cell transplantation. J. Neurotrauma, 21(4):383-93, 2004.

Metz, G. A.; Merkler, D.; Dietz, V.; Schwab, M. E. \& Fouad, K. Efficient testing of motor function in spinal cord injured rats. Brain Res., 883(2):165-77, 2000.

Nagaraju, K.; Carlson, G. \& De Luca, A. Behavioural and Locomotor Measurements Using Open Field Animal Activity Monitoring System. DMD_M2.1.002 Washington D. C., TREAT-NMD Neuromuscular Network, Wellstone Muscular Dystrophy Center, 2010. Available from: http://www.treat-nmd.eu/downloads/file/sops/dmd/MDX/ DMD_M.2.1_002.pdf

Nandoe Tewarie, R. D.; Hurtado, A.; Ritfeld, G. J.; Rahiem, S. T.; Wendell, D. F.; Barroso, M. M.; Grotenhuis, J. A. \& Oudega, M. Bone marrow stromal cells elicit tissue sparing after acute but not delayed transplantation into the contused adult rat thoracic spinal cord. $J$. Neurotrauma, 26(12):2313-22, 2009b.

Nandoe Tewarie, R. S.; Hurtado, A.; Bartels, R. H.; Grotenhuis, A. \& Oudega, M. Stem cell-based therapies for spinal cord injury. J. Spinal Cord Med., 32(2):105-14, 2009a.
Ogawa, Y.; Sawamoto, K.; Miyata, T.; Miyao, S.; Watanabe, M.; Nakamura, M.; Bregman, B. S.; Koike, M.; Uchiyama, Y.; Toyama, Y. \& Okano, $\mathrm{H}$. Transplantation of in vitro-expanded fetal neural progenitor cells results in neurogenesis and functional recovery after spinal cord contusion injury in adult rats. J. Neurosci. Res., 69(6):925-33, 2002.

Onifer, S. M.; Rabchevsky, A. G. \& Scheff, S. W. Rat models of traumatic spinal cord injury to assess motor recovery. ILAR J., 48(4):385-95, 2007.

Raben, N.; Nagaraju, K.; Lee, E. \& Plotz, P. Modulation of disease severity in mice with targeted disruption of the acid alpha-glucosidase gene. Neuromuscul. Disord., 10(4-5):283-91, 2000.

Ramadan, W. S.; Abdel-Hamid, G. A.; Al-Karim, S. \& Abbas, A. T. Histological, immunohistochemical and ultrastructural study of secondary compressed spinal cord injury in a rat model. Folia Histochem. Cytobiol., 55(1):11-20, 2017.

Rawson, R. L.; Yam, L.; Weimer, R. M.; Bend, E. G.; Hartwieg, E.; Horvitz, H. R.; Clark, S. G. \& Jorgensen, E. M. Axons degenerate in the absence of mitochondria in C. elegans. Curr. Biol., 24(7):760-5, 2014.

Sali, A.; Guerron, A. D.; Gordish-Dressman, H.; Spurney, C. F.; Iantorno, M.; Hoffman, E. P. \& Nagaraju, K. Glucocorticoid-treated mice are an inappropriate positive control for long-term preclinical studies in the mdx mouse. PLoS One, 7(4):e34204, 2012.

Sharp, J.; Frame, J.; Siegenthaler, M.; Nistor, G. \& Keirstead, H. S. Human embryonic stem cell-derived oligodendrocyte progenitor cell transplants improve recovery after cervical spinal cord injury. Stem Cells, 28(1):152-63, 2010.

Takahashi, K. \& Yamanaka, S. Induction of pluripotent stem cells from mouse embryonic and adult fibroblast cultures by defined factors. Cell, 126(4):663-76, 2006.

Tatem, K. S.; Quinn, J. L.; Phadke, A.; Yu, Q.; Gordish-Dressman, H. \& Nagaraju, K. Behavioral and locomotor measurements using an open field activity monitoring system for skeletal muscle diseases. J. Vis. Exp., (91):51785, 2014.

Thuret, S.; Moon, L. D. \& Gage, F. H. Therapeutic interventions after spinal cord injury. Nat. Rev. Neurosci., 7(8):628-43, 2006.

Vinay, L.; Brocard, F.; Clarac, F.; Norreel, J. C.; Pearlstein, E. \& Pflieger, J. F. Development of posture and locomotion: an interplay of endogenously generated activities and neurotrophic actions by descending pathways. Brain Res. Brain Res. Rev., 40(1-3):118-29, 2002.

Wu, B. \& Ren, X. J. Control of demyelination for recovery of spinal cord injury. Chin. J. Traumatol., 11(5):306-10, 2008.

\section{Corresponding author: \\ Dr. Ghada A Abdel-Hamid \\ Associate professor of anatomy \\ King Abdulaziz University \\ KSA}

Email: ghada169@hotmail.com

Received: 17-07-2018

Accepted: 01-10-2018 